\title{
Distribution of acoustically determined biomass and major zooplankton taxa in the upper mixed layer relative to water masses in the western Aleutian Islands
}

\author{
Kenneth O. Coyle ${ }^{1, *}$, Thomas J. Weingartner ${ }^{1}$, George L. Hunt $\mathrm{Jr}^{2}$ \\ ${ }^{1}$ Institute of Marine Science, University of Alaska, Fairbanks, Alaska 99775-7220, USA \\ ${ }^{2}$ Department of Ecology and Evolutionary Biology, University of California, Irvine, California 92717, USA
}

\begin{abstract}
Hydrographic, acoustic and zooplankton data were collected during June 1992 and June 1995 along transects to the north and south of Kiska and Buldir Islands in the western Aleutian Islands to look for mesoscale relationships between zooplankton community composition, biomass, and associated frontal systems and pycnoclines. Hydrographic data revealed a front dividing the Bering Sea water mass from the mixed regime in the passes and Alaska Stream water south of the islands. Chlorophyll concentration and $\mathrm{ADB}$ (acoustically determined biomass) were consistently higher on the Bering Sea side of the front in June 1992. Elevated ADB in the Bering Sea was due to aggregates of Neocalanus cristatus copepodid $\mathrm{V}$ in the pycnocline separating the upper mixed layer from the underlying cold intermediate layer. $N$. cristatus abundance was significantly higher $(\mathrm{p}<0.05)$ in Bering Sea water in June 1992 than in Pacific water in June 1992 and Bering Sea water in June 1995. N. fleminger abundance was significantly higher in Bering Sea water than in Pacific water in both 1992 and 1995 $N$. plumchrus and Eucalanus bungii stages III and IV were more abundant in Pacific water than in Bering Sea water. The results clearly demonstrate the utility of interfacing acoustics, net samples and hydrographic data to elucidate mesoscale associations of zooplankton to fronts, water masses and pycnoclines.
\end{abstract}

KEY WORDS: Zooplankton - Acoustics - Water masses - Aleutian Islands

\section{INTRODUCTION}

The zooplankton fauna of the Bering Sea is divided into 4 major faunistic groups (Vinogradov 1956). The southern Bering Sea oceanic group consists of calanoid taxa occurring in both the Bering Sea and the northern Gulf of Alaska (Brodsky 1957). Despite the similarity in zooplankton species composition in the Bering Sea and North Pacific, plankton surveys to the north and south of the western Aleutian Islands over a 15 yr period revealed differences in mean biomass in the upper $80 \mathrm{~m}$ of the water column: $14.3-18.0$ versus $24.1-28.4 \mathrm{~g}$ $\mathrm{m}^{-3}$ to the south and north of the islands, respectively (Motoda \& Minoda 1974).

•E-mail: coyle@ims.alaska.edu
The differences in zooplankton biomass are probably related to differences in water mass types to the north and south of the Aleutians. The water mass to the south of the Aleutians consists of the Alaska Stream, a strong current which flows along the shelf break from the eastern Gulf of Alaska to the western Aleutian Islands, and forms the northern boundary of the Pacific subarctic gyre (Reed 1984). In contrast, water in the Bering Sea basin consists of resident Bering Sea water which mixes to a greater or lesser extent with Alaska Stream water, depending on the specific location and amount of flow through the Aleutian Islands passes (Reed et al. 1993, Pavlov \& Pavlov 1996). Given the different origins of the water masses to the south and north of the Aleutian Islands, the differences in zooplankton biomass may be due to differences in the 
relative abundance of the various taxa, or differences in the abundance of their developmental stages in the 2 water masses.

Examination of acoustic data from the Bering Sea basin north of Kiska Island in June 1992 revealed intense sound scattering in the pycnocline separating the upper mixed layer from the cold winter layer beneath (Coyle in press). Sound scattering in the layer was related primarily to dense aggregations of $\mathrm{Neo}$ calanus cristatus. In this paper, we examine the geographic distribution of sound scattering intensity and the species composition and abundance of major zooplankton taxa relative to the distribution of water masses of Pacific and Bering Sea origin. Firstly, we present 4 examples of the distribution of temperature, salinity, chlorophyll concentration and acoustically determined biomass (ADB) along transects crossing the front between Bering Sea water and Pacific water or the mixing regime in the passes. Secondly, we pool all transects and analyze the spatial distribution of ADB relative to the position of the front. Thirdly, we combined net tows to the south and to the north of the front to examine differences in species composition in the 2 water mass types. Finally, we compare data from 1992 and 1995 to address interannual variability. These observations may help explain the biomass differences observed earlier (Motoda \& Minoda 1974) and document the critical influence of frontal systems and pycnoclines on the mesoscale distribution of zooplankton biomass in the western Aleutian Islands.

\section{METHODS}

Study area and sampling schedule. The study area included regions around Buldir and Kiska Islands in the western Aleutian Islands (Fig. 1). The Aleutians are a string of volcanic peaks rising from the sea floor to several thousand meters above sea level and separate the Gulf of Alaska from the Bering Sea. The shelf is narrow, the continental slope is steep, and the plankton community is oceanic (Motoda \& Minoda 1974, Coyle et al. 1996). Sampling was done aboard the RV 'Alpha Helix' during June, in 1992 and 1995. The Kiska region was sampled twice in 1992: 6-11 June and 24-28 June; the Buldir region was sampled once: 13-23 June 1992; Kiska was sampled again on 6-7 June 1995. Zooplankton biomass was estimated from both net and acoustic data. Methods for collection and processing of net, acoustic and conductivity-temperature-depth profiler (CTD) data are outlined below.

Acoustics. Volume scattering intensity was measured at frequencies of 200 and $420 \mathrm{kHz}$ along transects at integration intervals of $30 \mathrm{~s}$ (horizontal distance covered $=120 \mathrm{~m}$ ) using a Biosonics model 120 echosounding system and integration board. The transducers were deployed in a $\mathrm{v}$-fin depressor at $3 \mathrm{~m}$ depth and towed at $4 \mathrm{~m} \mathrm{~s}^{-1}$ beside the vessel about $3 \mathrm{~m}$ from the hull. The $420 \mathrm{kHz}$ system resolved volume scattering in $1 \mathrm{~m}$ depth intervals from 5 to $55 \mathrm{~m}$ depth. Volume scattering was measured by the $200 \mathrm{kHz}$ system in $2 \mathrm{~m}$ depth intervals from 5 to $165 \mathrm{~m}$ depth. Volume scattering data from 1992 was converted to zooplankton biomass using regression analysis with net data and by application of a sound scattering model (Coyle in press). Volume scattering data from 1995 was converted to ADB by computing a scaler $\left(\mathrm{dB} \mathrm{g}^{-1}\right)$, using the average volume scattering from acoustic data along the net track (Coyle in press) and the average wet weight biomass from the concurrently collected zooplankton data. Model calculations and comparison of acoustic returns to net data indicated that the target strengths of the major zooplankton taxa in the study area were below $-80 \mathrm{~dB}$. Given the zooplankton densities we encountered and the acoustic returns measured, it was improbable that volume scattering above $-60 \mathrm{~dB}$ could be attributed to zooplankton; therefore, volume scattering above $-60 \mathrm{~dB}$ was discarded from the data. The ADB reported here is therefore a conservative estimate. Latitude and longitude were simultaneously recorded with a GPS (global positioning system) receiver interfaced to the computer.

The spatial distribution of ADB was computed using geostatistical techniques (Isaaks \& Srivastava 1989). The data between 7 and $45 \mathrm{~m}$ depth were integrated to produce $\mathrm{ADB}$ estimates in $\mathrm{g} \mathrm{m}^{-2}$. All data were $\mathrm{log}$ transformed before analysis and the position coordinates were converted to distance $(\mathrm{km})$ from the southeast corner of the grid in the $x$ (east-west) and $y$ (northsouth) directions. The distance between all points in the sample grids were computed and bin-averaged into $1 \mathrm{~m}$ bins. The variance with respect to distance was then modeled using standard spherical or exponential geostatistical models, depending on which best fit the data. Modeling produced values for the measurement error or 'nugget effect' and the range of influence. The appropriate variance model with the above parameters was then applied to a 2-dimensional kriging algorithm to produce predicted values and $95 \%$ confidence intervals for each block in a 40 by 40 array of blocks within the study area. The spatial analysis was done with software written in MATLAB programming language with calls to $\mathrm{C}$ subroutines. Coordinates in the output arrays were converted back to latitude and longitude to produce geographic plots of ADB using GMT (Generic Mapping Tool) software. Due to insufficient coverage in 1995, spatial analyses were done on the 1992 data only.

Zooplankton. Zooplankton were collected with a MOCNESS (multiple opening closing net and environ- 

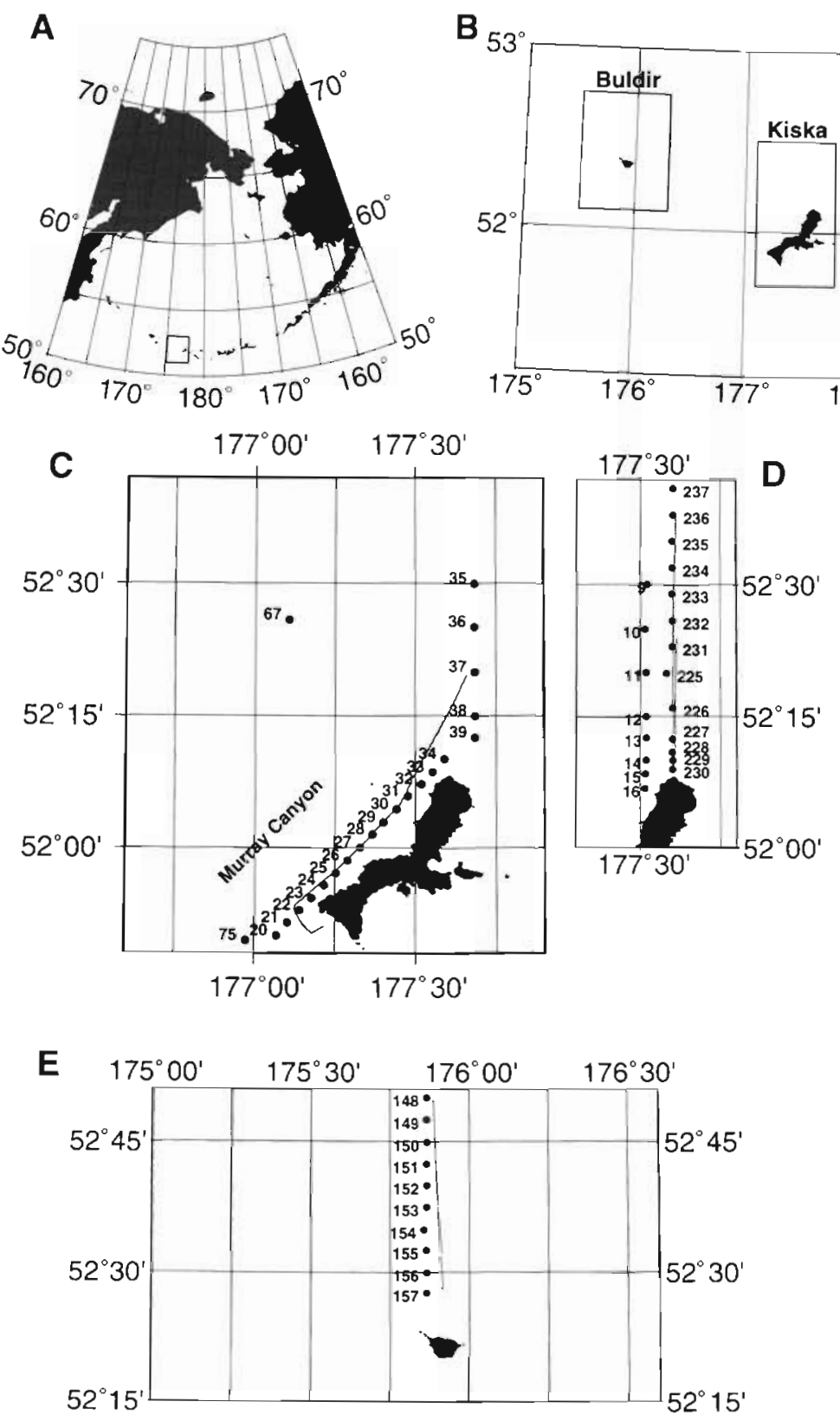

mental sampling system). Each tow consisted of up to 9 nets which were opened and closed at specific depths above, below and in the sound-scattering layers observed at each site. The mesh size of the MOCNESS nets was $0.505 \mathrm{~mm}$, the effective mouth opening was $1 \mathrm{~m}^{2}$, and the system simultaneously recorded conductivity, temperature, depth, fluorescence, volume fished and net angle. Samples were preserved in $10 \%$ formalin for later processing.

In the laboratory the samples were sequentially split with a Folsom splitter to produce a hierarchical series of subsamples containing a minimum of 100 to 200 organisms. Systematic examination of each subsample permitted identification and enumeration of the domi-
Fig. 1. (A, B) The study area in the western Aleutians near Buldir and Kiska Islands. CTD and acoustic transects in 1992: (C) through Murray Canyon between the Pacific and the Bering Sea side of Kiska Island, (D) north of Kiska Island and (E) north of Buldir Island. Solid lines indicate acoustic transect lines nant organisms of each major size category in the samples. The specimens were sorted and identified to the lowest taxonomic level possible, copepodid stages were determined and wet weights were measured using a Cahn c-30 microbalance. Analyses were done with an INGRES database and FORTRAN software with calls to IMSL statistical routines.

Hydrography. Conductivity-temperaturedepth measurements were collected with a Neil Brown CTD. In situ fluorescence was measured with a model $Q$ fluorometer mounted on the CTD. The in situ fluorometer was calibrated using water samples collected at discrete depths. The samples were extracted in $90 \%$ acetone and fluorescence was measured on a Turner Design bench fluorometer as outlined in Parsons et al. (1984). The bench fluorometer was calibrated using a Hitachi spectrophotometer and chlorophyll a extract as outlined in Parsons et al. (1984). Measurements of surface salinity and temperature were taken every 0.5 to $2 \mathrm{~min}$ along transects using Seabird sensors mounted in a sea chest on the ship. The surface data were transferred to a computer interfaced with the ship's GPS to provide date, time and position for each ensemble.

All contour plots of the hydrographic data were computer generated using a minimum curvature gridding algorithm. The south end of the transects is on the left side of all plots shown.

\section{-RESULTS}

\section{Water masses and ADB}

Four transects crossing the front between Bering Sea water and the mixed regime in the passes to the south illustrate north-south changes in the depth distribution of salinity, temperature, fluorescence and ADB: 
1 through Murray Canyon between the Pacific and the Bering Sea side of Kiska Island (Fig. 1C), 2 north of Kiska Island (Fig. 1D) and 1 north of Buldir Island (Fig. 1E). The CTD transects were taken within $24 \mathrm{~h}$ of the acoustic transects.

The water column north and south of the Aleutian Islands showed greater thermo- and halostratification than the water column in the passes (Fig. 2). Elevated surface salinity and lower surface temperature in the passes relative to regions north and south of the islands indicated mixing (Fig. 2). The southern boundary of Bering Sea surface water occurred at a fairly sharp front between $52.1^{\circ}$ and $52.2^{\circ} \mathrm{N}$. The downward slope of isohaline lines between $52.2^{\circ}$ and $52.4^{\circ} \mathrm{N}$ (Fig. 2) suggests convergent flow. Elevated chlorophyll concentrations were measured on the northern stratified side of the Bering Sea front. A distinct surface front also occurred between $51.9^{\circ}$ and $52.0^{\circ} \mathrm{N}$, near the southern end of Kiska Island (Fig. 2). Pacific Ocean surface water was characterized by elevated temperatures and low salinities. In contrast to the Bering Sea front, elevated chlorophyll concentrations were not observed on the southern stratified side of the Pacific Ocean front. ADB was elevated in the upper mixed layer along the transects north of the Bering Sea front (Fig. 2) but was absent south of the front.

The major difference between water masses north and south of the Aleutian Islands was the presence of the cold winter remnant layer north of the Bering Sea front. The winter layer appears as a temperature depression between 50 and $200-250 \mathrm{~m}$ depth on temperature-salinity diagrams when stations at the opposite ends of transects through Murray Canyon are compared (Figs. 1C \& 3). Water masses below the winter layer were similar on both sides of the Aleutian archipelago.

Transects north of Kiska on 8 June 1992 showed elevated chlorophyll concentrations and $\mathrm{ADB}$ north of the Bering Sea front (Stns 33 and 34; Fig. 1C); ADB extended as a fairly continuous layer from the front to the end of the transect (Fig. 4). Consecutive runs of the acoustic transect revealed consistent layers of maximum ADB near the 26.12 isopycnal line. The scattering layer ascended northward with the shallowing pycnocline and surfaced between $52.3^{\circ}$ and $52.4^{\circ} \mathrm{N}$, just

Stations 20-39, 9-10 June 1992
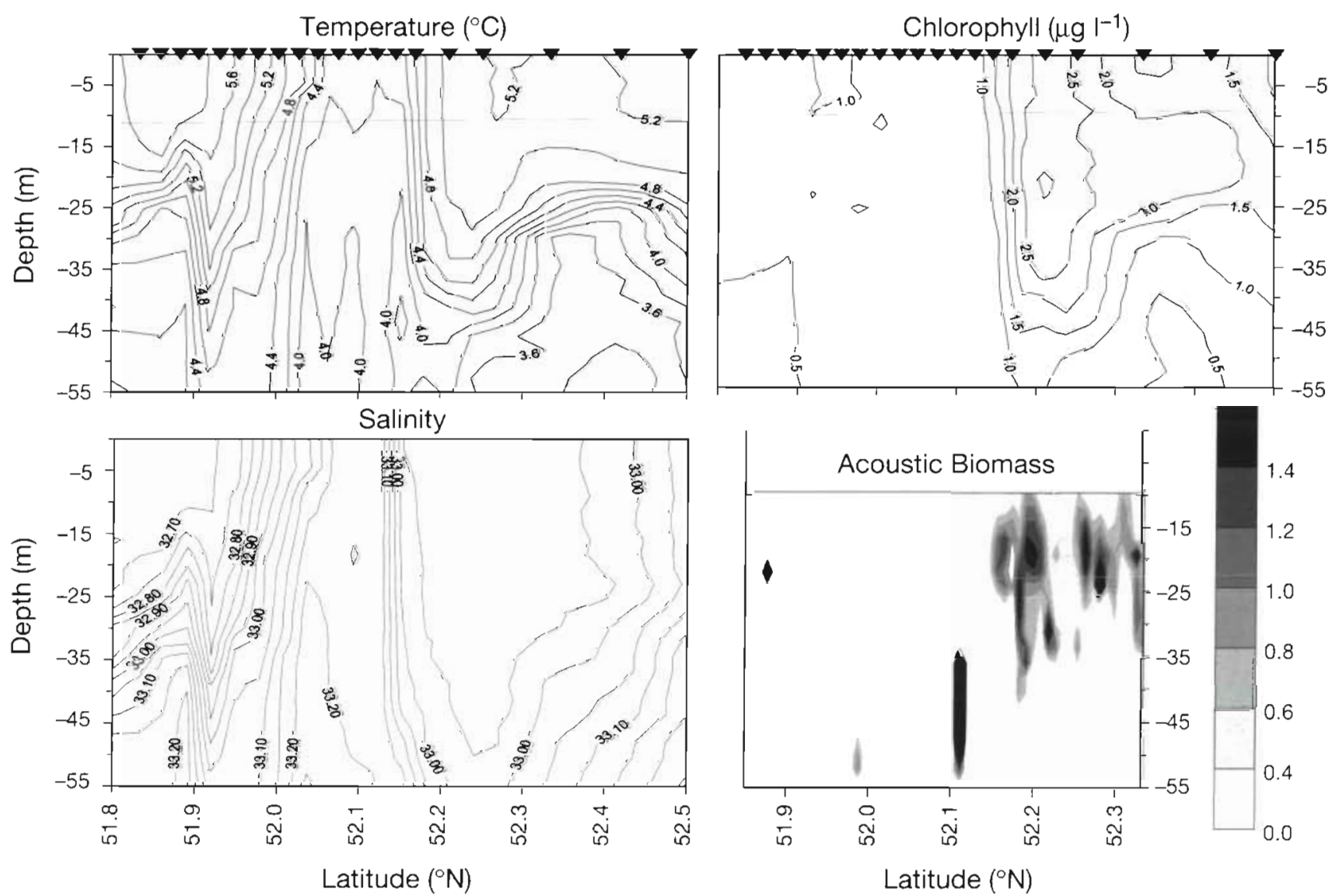

Fig. 2. Temperature, salinity, chlorophyll and acoustic biomass $\left(\mathrm{g} \mathrm{m}^{-3}\right.$ ) profiles along a transect through Murray Canyon (Fig. $1 \mathrm{C}_{i}$ Stns 20 to 39). Triangles along top axis mark locations of stations. Horizontal axes on upper and lower figures are aligned 

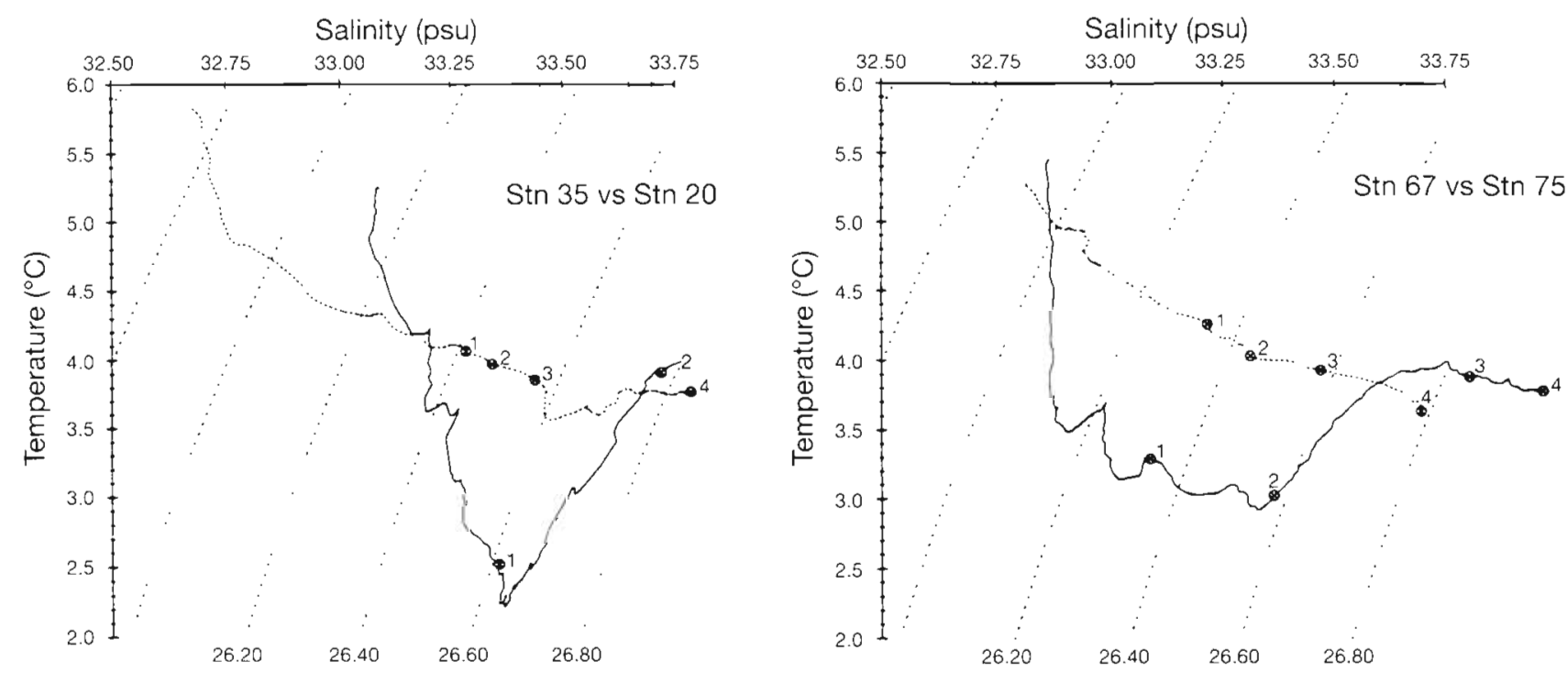

Fig. 3. Temperature salinity plots for northern stations (35 and 67 ; solid lines), and southern stations (20 and 75, dotted lines) (station locations in Fig. 1C) taken in June 1992 near Kiska Island. Numbers 1 through 4 are depth markers between 100 and $400 \mathrm{~m}$ depth. Dashed lines are density $\left(\sigma_{t}\right)$

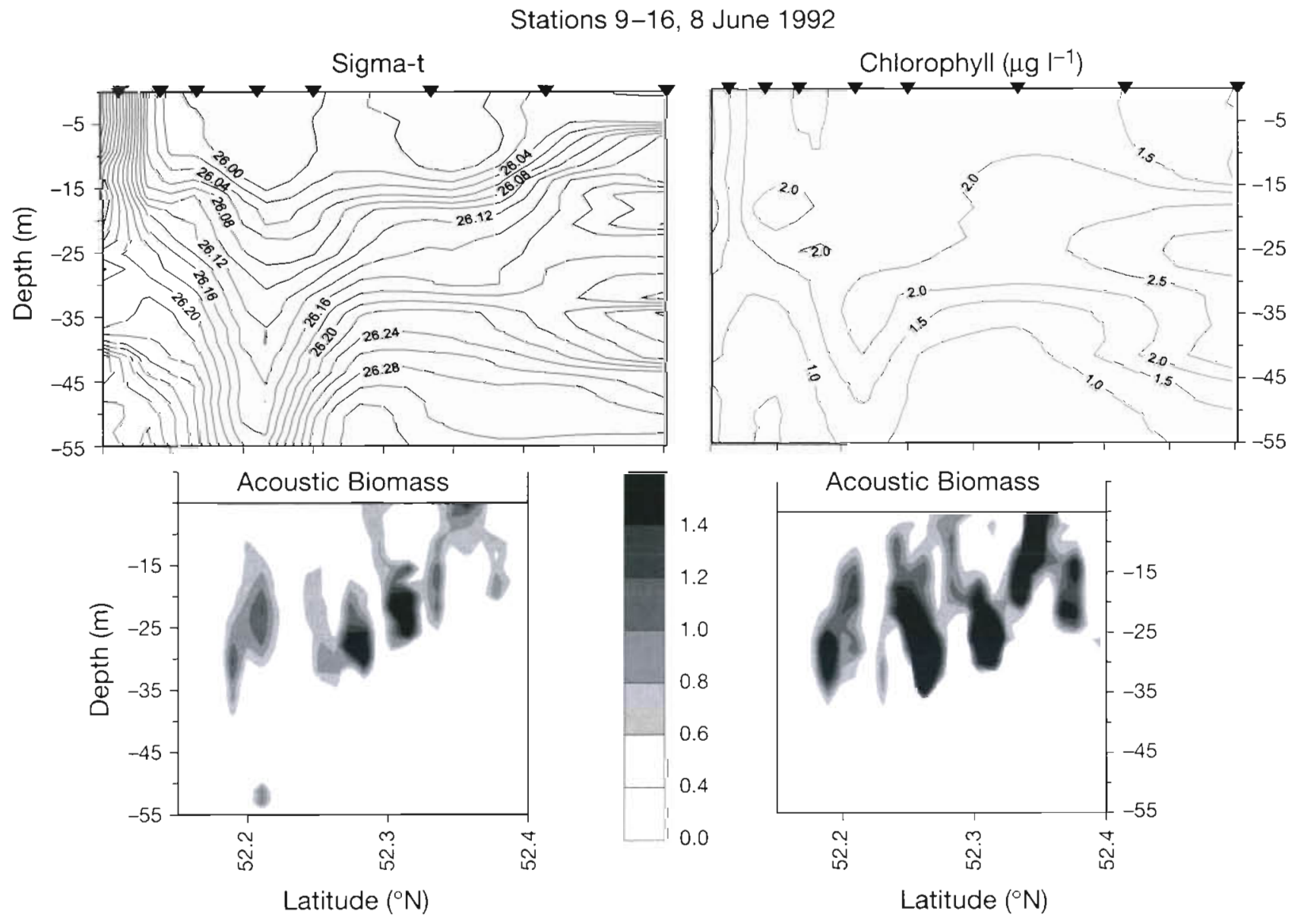

Fig. 4. Density, chlorophyll and replicate acoustic biomass $\left(\mathrm{g} \mathrm{m}^{-3}\right)$ profiles taken sequentially in June along a transect north of Kiska Island (Stns 9 to 16 and the short acoustic transect; Fig. 1D). Triangles along upper axes mark CTD station locations. Horizontal axes on upper and lower figures are aligned 
south of the minimum pycnocline depth. A fairly strong convergence is suggested around $52.2^{\circ} \mathrm{N}$, where the isopycnals formed a trough (Fig. 4 i see also Fig. 2). By late June the region of maximum chlorophyll was north of $52.5^{\circ} \mathrm{N}$, where dense aggregates of sound-scattering organisms were observed above the pycnocline in the chlorophyll maximum layer (Fig. 5). Aggregates also occurred in the thermocline south to the salinity front at $52.25^{\circ} \mathrm{N}$. CTD transects near Buldir Island also revealed distinct frontal regions. Elevated chlorophyll concentrations and ADB occurred in Bering Sea surface water on the stratified side of the front (Fig. 6).

Two additional transects were run north of Kiska in June 1995 (Fig. 7); the western transect is plotted in Fig. 8. Chlorophyll distributions along the transect suggested the presence of a phytoplankton bloom to the north of $52.5^{\circ} \mathrm{N}$. In addition, contours of salinity and temperature indicated a region of somewhat greater mixing above the pycnocline north of $52.5^{\circ} \mathrm{N}$. Sound scattering south of $52.5^{\circ} \mathrm{N}$ was close to or below the threshold of detection, while scattering to the north was elevated in the upper $10 \mathrm{~m}$ and below the pycnocline (Fig. 8). Net tow data indicated the presence of Thysanoessa longipes and $T$. inspinata in the scattering layers below the pycnocline.

In summary, although fronts on both sides of the Aleutian ridge separated mixing zones in the passes, elevated chlorophyll and acoustic biomass were confined to the stratified side of the Bering Sea front, where surface water occurred over a cold winter layer with temperatures under $4^{\circ} \mathrm{C}$ to depths of $200 \mathrm{~m}$ during June 1992. Sound scattering in June 1995 was much weaker than in 1992 and limited to regions north of $52.5^{\circ} \mathrm{N}$, where a phytoplankton bloom was apparently occurring.

\section{Spatial analyses of integrated data}

Both spherical and exponential models (Isaaks \& Srivastava 1989) were used to model spatial correlations, the $r^{2}$ values were $0.88-0.97$, the range of influ-
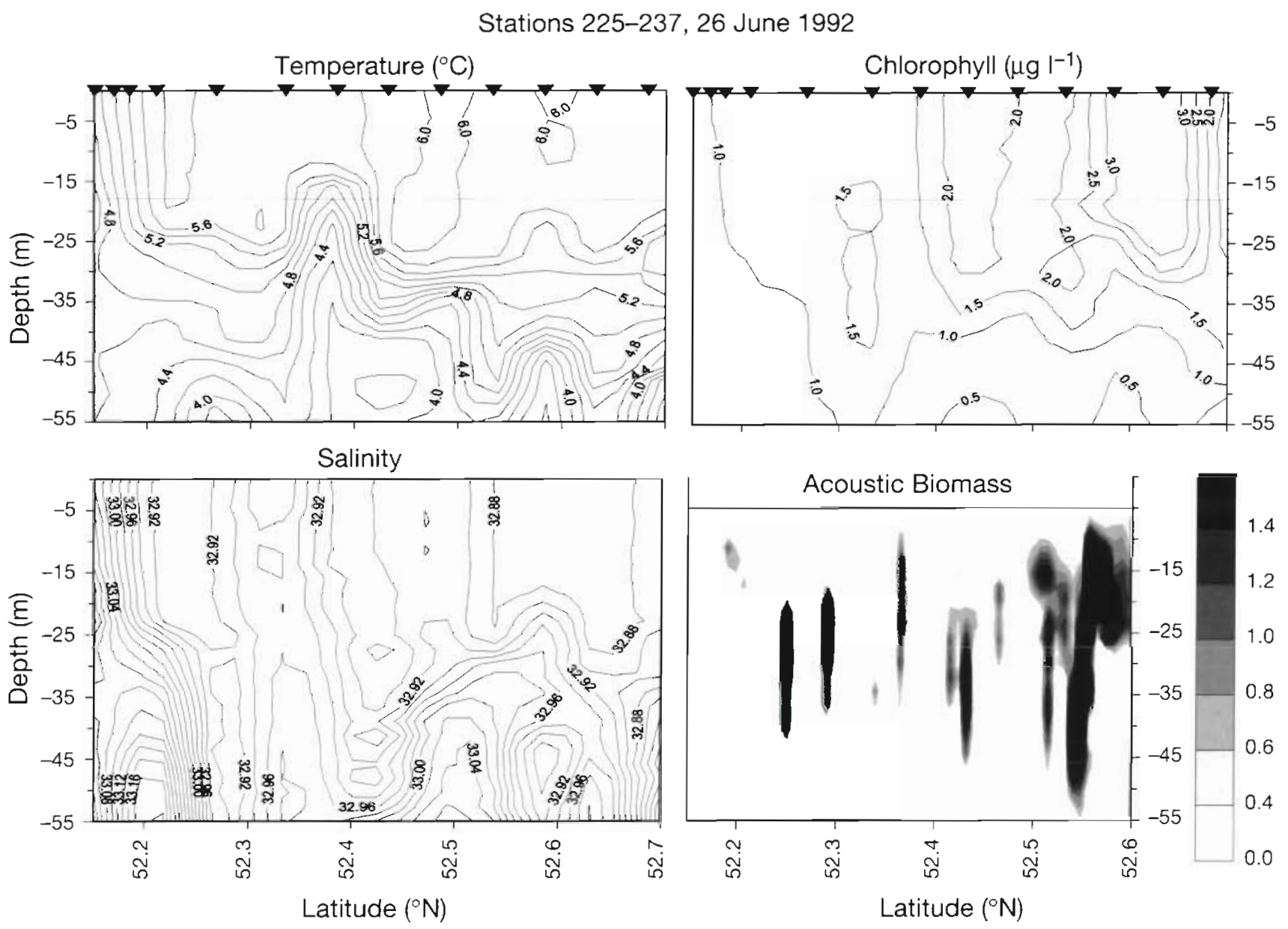

Fig. 5. Temperature, salinity, chlorophyl and acoustic biomass $\left(\mathrm{g} \mathrm{m}^{-3}\right)$ profiles taken in June along a transect north of Kiska Island (Stns 225 to 237 and the long acoustic transect; Fig. 1D). Triangles along upper axes mark CTD station locations. Horizontal axes on upper and lower figures are aligned 

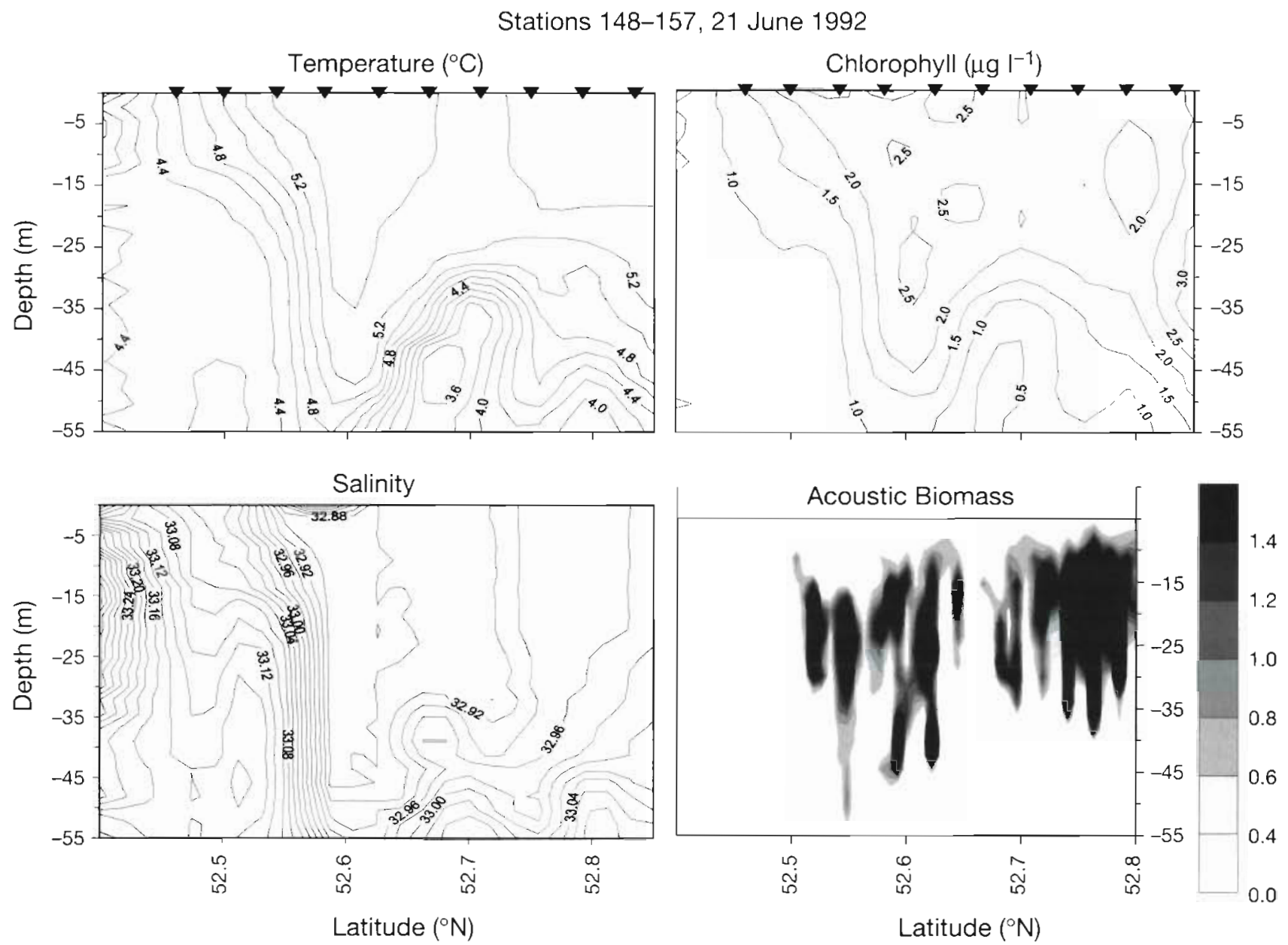

Fig. 6. Temperature, salinity, chlorophyll and acoustic biomass $\left(\mathrm{g} \mathrm{m}^{-3}\right)$ profiles taken in June along a transect north of Buldir Island (Stns 148 to 157; Fig. 1E). Triangles along upper axes mark CTD station locations. Horizontal axes on upper and lower figures are aligned

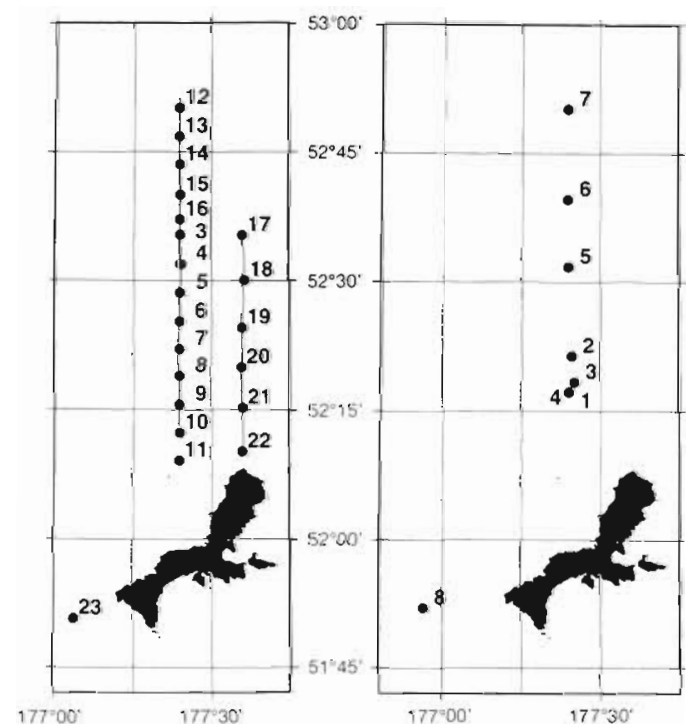

Fig. 7. CTD and acoustic transects taken on 6 and 7 June 1995 north of Kiska Island (left). Locations of MOCNESS tows (right) ence was $12.4-26.9 \mathrm{~km}$, and spatial correlations accounted for up to $40-58 \%$ of the variance (Table 1). Both predicted values (geometric mean values) and the lower $95 \%$ confidence values are mapped for each region (Figs. 9 to 11 ). The cruise track is plotted over the predicted values and contours of sea surface temperature are plotted over the lower confidence values. Tightest confidence intervals occurred in regions on

Table 1 Results from covariance models for acoustically determined biomass (ADB) from around Buldir Island and Kiska Island in 1992

\begin{tabular}{|lccc|}
\hline & \multicolumn{2}{c}{ Kiska } & Buldir \\
& $6-11$ June & $24-28$ June & 13-23 June \\
\hline Model type & Exponential & Spherical & Exponential \\
Nugget effect & 0.56 & 0.42 & 0.60 \\
Range $(\mathrm{km})$ & 12.4 & 26.9 & 26.8 \\
$\mathrm{r}^{2}$ & 0.97 & 0.97 & 0.88 \\
& & & \\
\hline
\end{tabular}


or surrounded by transects. As the distance from the nearest transect increased, the confidence intervals broadened and the lower confidence values approached zero. Therefore, predicted values along or between cruise tracks are primarily influenced by measured values, while values further from the cruise track are more influenced by model predictions, resulting in broad confidence intervals surrounding the predictions. For the above reasons, we take the lower confidence values as reasonable conservative estimates of $\mathrm{ADB}$ in each prediction block. However, both the lower confidence values and predicted values are presented to illustrate the resulting differences in $A D B$ distribution.

The surface expression of the front separating Bering Sea water from water masses to the south occurred as a band of closely packed isothermal lines running northwest from $52^{\circ} 15^{\prime} \mathrm{N}, 176^{\circ} \mathrm{W}$ to $52^{\circ} 45^{\prime} \mathrm{N}, 175^{\circ} 30^{\prime} \mathrm{W}$ near
Buldir Island (Fig. 9). Elevated surface temperatures occurred to the north and east of the front and formed the upper mixed layer shown in Fig. 6. Areas of elevated $\mathrm{ADB}$ occurred primarily north of the front (Fig. 9). Although several regions with predicted values over $20 \mathrm{~g}$ $\mathrm{m}^{-2}$ occurred south of the front, the broad confidence intervals around the predictions resulted in minimal values for the lower $95 \%$ confidence estimates. Areas of elevated ADB also occurred north of the Bering Sea front near Kiska Island (Figs. 10 \& 11). ADB aggregates were closer to Kiska during early June (Fig. 10) than late June (Fig. 11). This above observation conforms with patterns on individual transects in the Kiska region (Figs. 2, 4 \& 5). The depressed isopycnals near the front in transects from early June (Figs. 2 \& 4 ) may have resulted from a warm-core eddy near the north end of Kiska Island (Fig. 10). There was no evidence of an eddy in the region during late June (Figs. 5 \& 11).
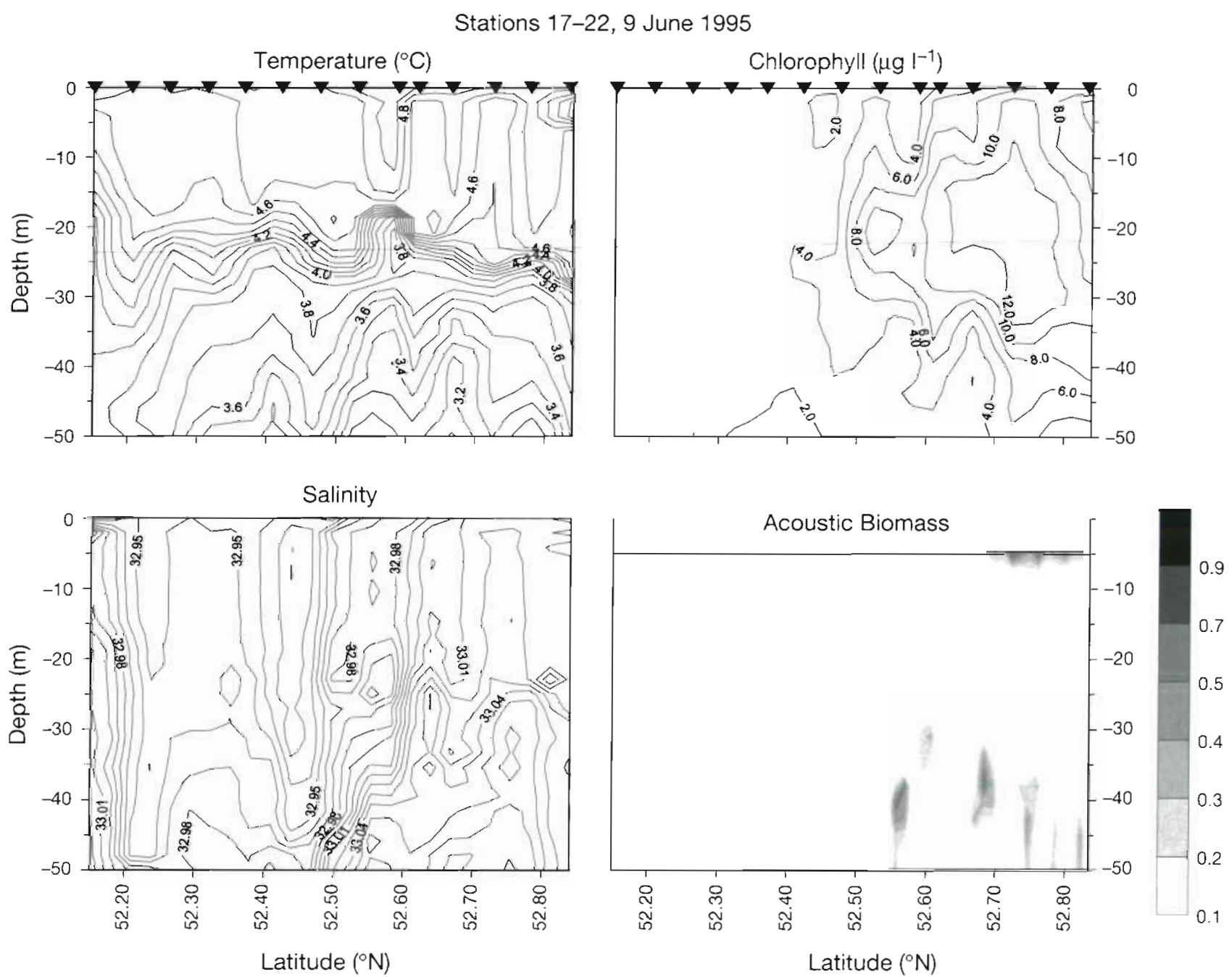

Fig. 8. Temperature, salinity, chlorophyll and acoustic biomass $\left(\mathrm{g} \mathrm{m}^{-3}\right)$ profiles along a transect north of Kiska Island (Stns $17-22$; Fig. 7). Triangles along upper axes mark CTD station locations. Horizontal axes on upper and lower figures are aligned 
Fig. 9. (A) Predicted values of acoustically determined zooplankton biomass from kriging analy. ses of data along cruise tracks near Buldir Island, 13 to 23 June 1992. (B) Lower $95 \%$ confidence interval of predicted values and contours of sea surface temperature $\left({ }^{\circ} \mathrm{C}\right)$
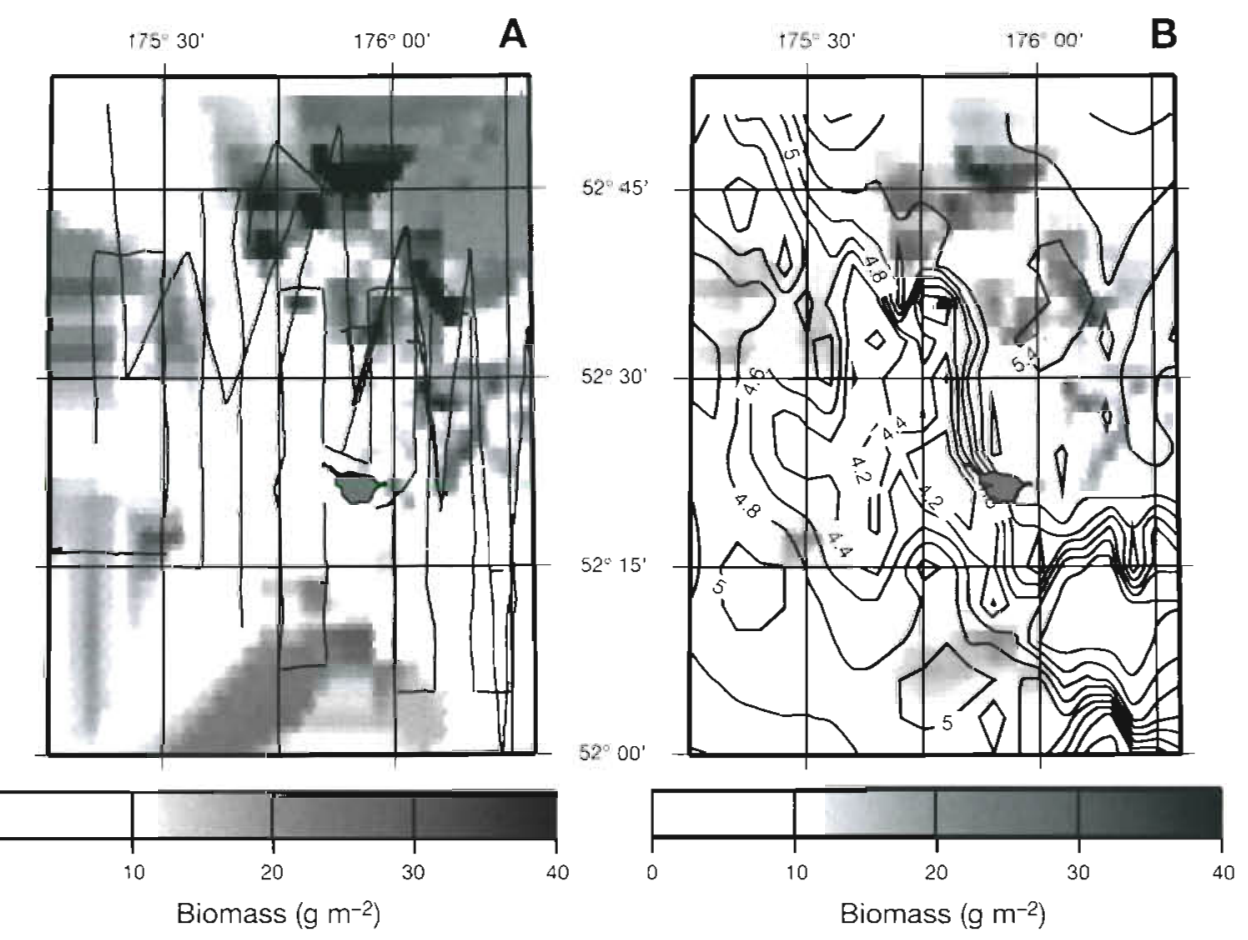

\section{Species composition}

Abundance estimates from the zooplankton net hauls taken in the upper $45 \mathrm{~m}$ at each station were averaged to produce a single value for each taxon at each station (Figs. $7 \& 12$ ). The stations were grouped by water mass type and year, and analysis of variance was performed to test for differences in the mean abundance of the major taxa by group (Table 2). Neocalanus flemingeri was more abundant in Bering Sea water in both 1992 and 1995 than in Pacific water in 1992. In contrast, N. plumchrus was more abundant in Pacific water in 1992 than in Bering Sea water. $N$. plumchrus dominated in 2 out of 3 samples in the upper $100 \mathrm{~m}$ from south of Kiska in 1995 (Stn 8, Fig. 7); however, N. flemingeri consistently dominated below $100 \mathrm{~m}$ depth.
Fig. 10. (A) Predicted values of acoustically determined zooplankton biomass from kriging analyses of data along cruise tracks north of Kiska Island, 6 to 11 June 1992. (B) Lower $95 \%$ confidence interval of predicted values and contours of sea surface temperature $\left({ }^{\circ} \mathrm{C}\right)^{-}$
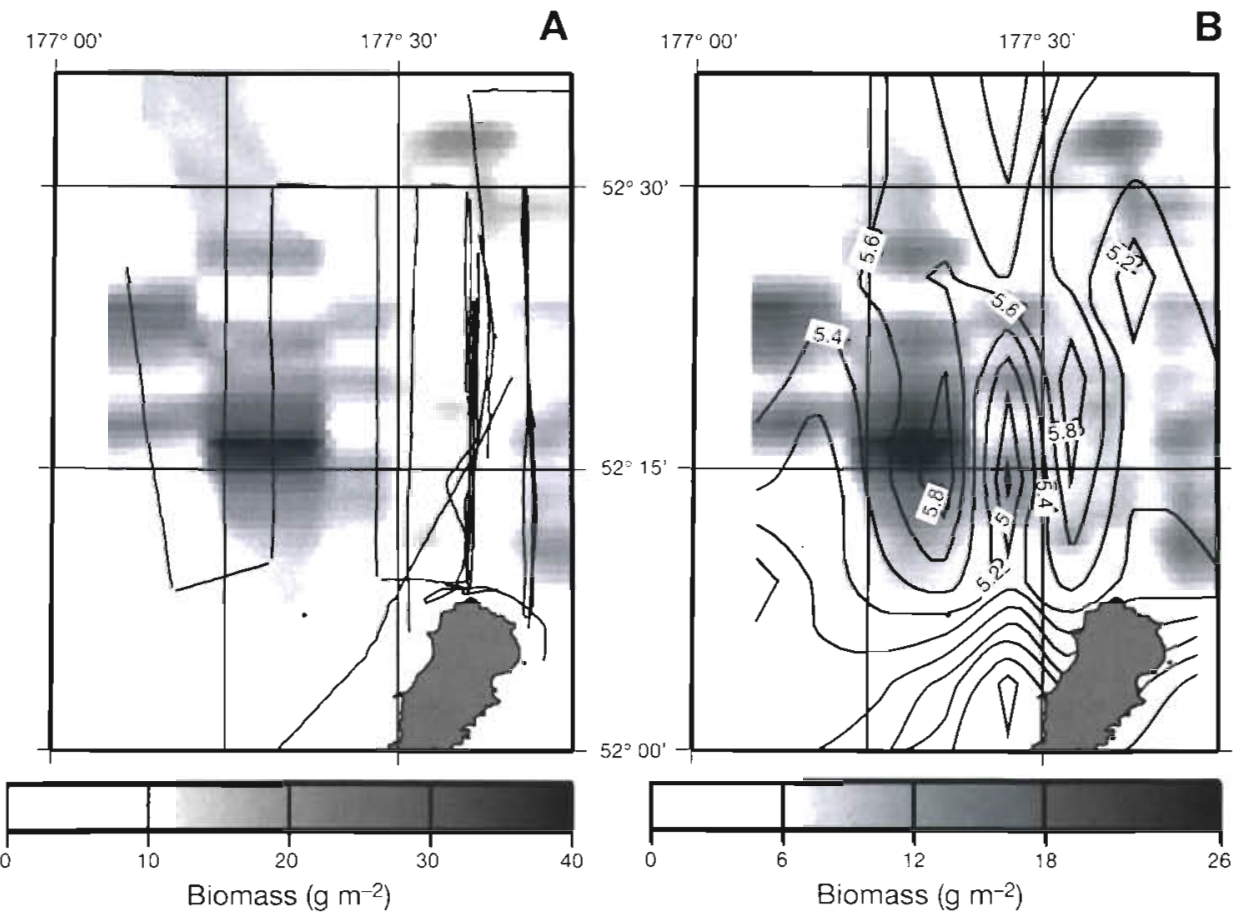

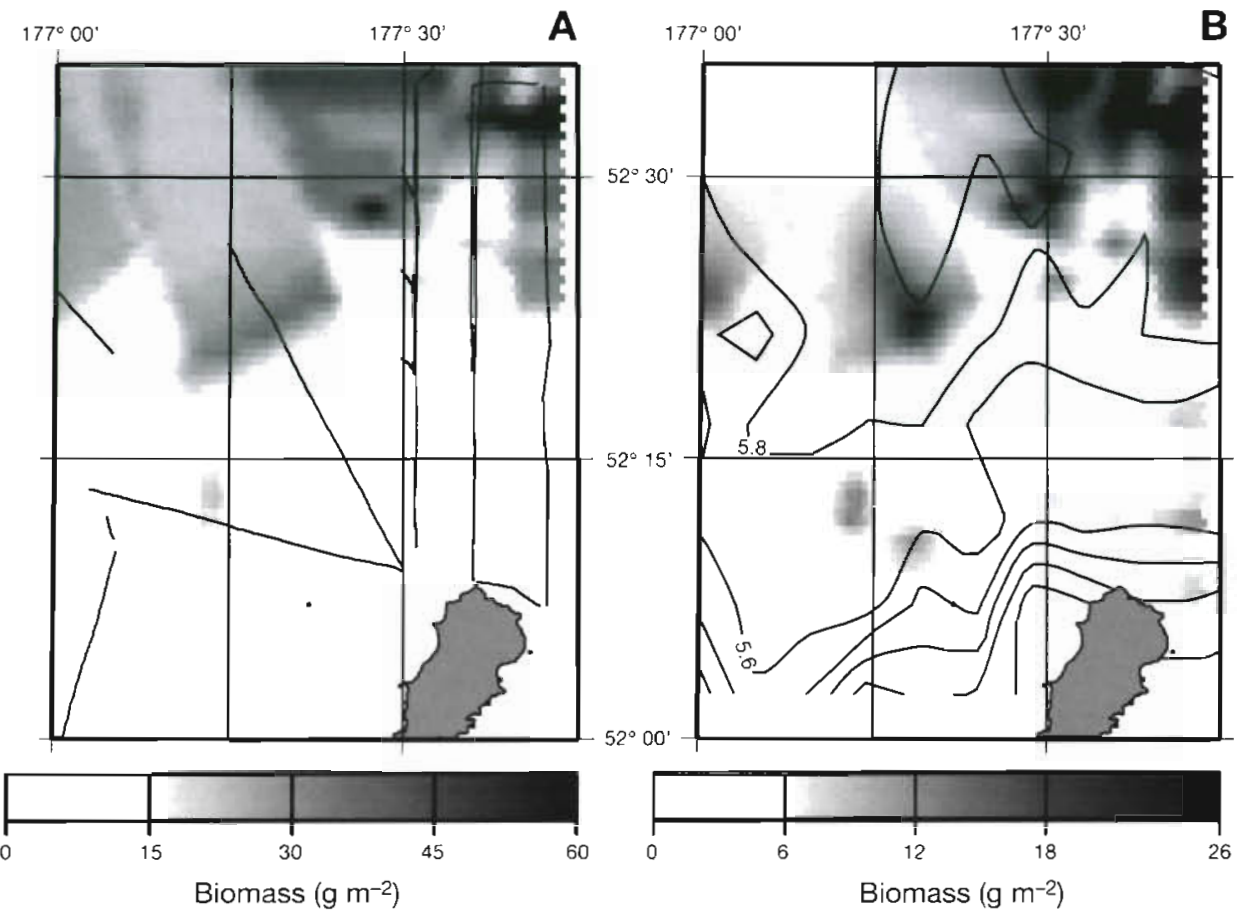

Fig. 11. (A) Predicted values of acoustically determined zooplankton biomass from kriging analyses of data along cruise tracks north of Kiska Island, 24 to 28 June 1992. (B) Lower $95 \%$ confidence interval of predicted values and contours of sea surface temperature $\left({ }^{\circ} \mathrm{C}\right)$
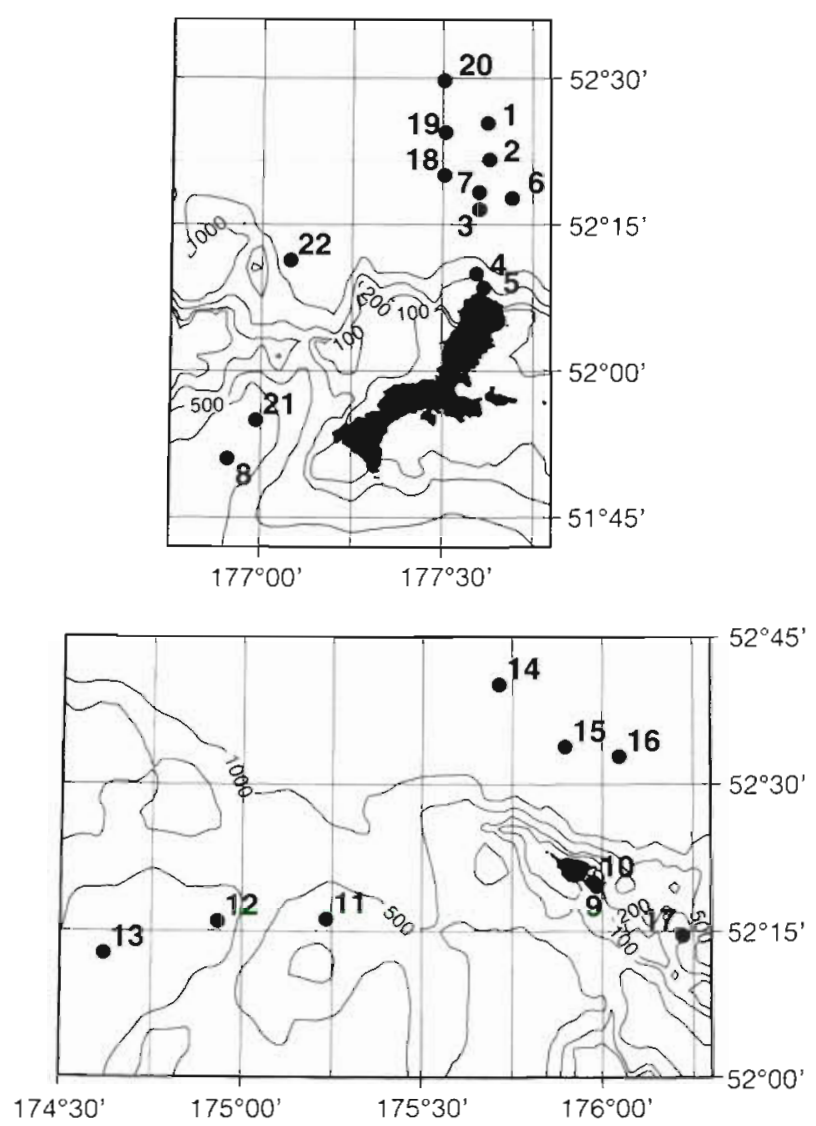

Fig. 12. Location of MOCNESS tows taken in June 1992 near Kiska Island (upper) and Buldir Island (lower). Depth contours in $\mathrm{m}$
Neocalanus cristatus was more abundant in Bering Sea water in 1992 than in Pacific water in 1992 and Bering Sea water in 1995 (Table 2). At Stn 8 south of Kiska Island, N. cristatus copepodids III-V were more abundant at 100 to $150 \mathrm{~m}$ depth than above or below. Copepodids III and IV of Eucalanus bungii were more abundant in Pacific water than in Bering Sea water.

\section{DISCUSSION}

The consistent differences outlined above in the abundances of Neocalanus plumchrus, $N$. flemingeri and Eucalanus bungii relative to the Bering Sea and Pacific sides of the Aleutians are probably related to differences in origin of the water masses on either side of the archipelago. Water to the north of the Bering Sea front was apparently resident Bering Sea water, as indicated by the cold intermediate layer between 50 and $200 \mathrm{~m}$ depth. The intermediate layer is produced by cooling and convective mixing of the surface layer during winter (Pavlov \& Pavlov 1996) and is conspicuously absent south of the Aleutian archipelago (Reed \& Stabeno 1993). Alaska Stream water occurs south of the Pacific Ocean front and is characterized by temperatures above $4^{\circ} \mathrm{C}$ to depths of about $200 \mathrm{~m}$ (Reed 1984 , Stabeno \& Reed 1992). The Alaska Stream is an intense, westward flowing current with a maximum speed of about $100 \mathrm{~cm} \mathrm{~s}^{-1}$ and an average transport of $12 \times 10^{6} \mathrm{~m}^{3} \mathrm{~s}^{-1}$ (Reed 1984). It flows along the shelf break from the eastern Gulf of Alaska to the western 
Table 2. Mean abundance (ind. $\mathrm{m}^{-3}$ ) of the dominant taxa near Kiska and Buldir Islands during June 1992 and June 1995. Ber92 (1): Bering Sea stations in 1992: 1, 2, 3, 6, 7, 14, 15, 16, 18, 19, 20; Pac92 (2): Pacific stations in 1992: 8, 9, 10, 11, 12, 13, 17, 21; Ber95 (3): Bering Sea stations in 1995: 1, 2, 3, 4, 5, 6, 7; see Figs. $7 \& 12$. $\mathrm{p}$ is the probability of equal means, Tukey: Tukey test for equal means ( $p=0.05)$. Stations 4,5 and 22 (Fig. 12) were in the mixed regime of the passes. As they could not be assigned to either Pacific or Bering Sea water masses, they are not included in this table. Since only tow 8 was taken in Pacific water south of Kiska in 1995, and most samples from the tow were from below the pycnocline, it could not be used in analysis of variance tests for differences between water masses in 1995

\begin{tabular}{|lccccc|}
\hline Taxon & Ber92 & Pac92 & Ber95 & $p$ & Tukey \\
\hline Neocalanus Il & 1.6457 & 1.1682 & 1.2372 & 0.4311 & \\
Neocalanus III & 7.2900 & 5.9910 & 13.1762 & 0.1684 & \\
Neocalanus IV & 19.7036 & 14.4961 & 5.5429 & 0.0079 & $1>3$ \\
Neocalanus flemingeri V & 9.2038 & 1.9968 & 20.9055 & 0.0001 & $2<1$ and 3 \\
Neocalanus plumchrus V & 2.8698 & 6.3046 & 1.1064 & 0.0001 & $2>1>3$ \\
Neocalanus cristatus II & 1.0942 & 1.4004 & 0.0000 & 0.2745 & \\
Neocalanus cristatus III & 1.7414 & 1.5488 & 1.0008 & 0.0438 & $1>3$ \\
Neocalanus cristatus IV & 2.4753 & 1.4004 & 1.0008 & 0.0023 & $1>2$ and 3 \\
Neocalanus cristatus V & 16.4231 & 1.7478 & 1.3905 & 0.0000 & $1>2$ and 3 \\
Eucalanus bungii II & 2.8660 & 4.8837 & 1.0499 & 0.0012 & $3<1$ and 2 \\
Eucalanus bungii III & 6.0004 & 24.5471 & 1.2339 & 0.0000 & $2>1>3$ \\
Eucalanus bungii IV & 3.4313 & 10.5015 & 1.2244 & 0.0006 & $2>1$ and 3 \\
Eucalanus bungii V & 2.6248 & 4.9545 & 2.2268 & 0.2779 & \\
Eucalanus bungii AF & 1.8777 & 2.6993 & 9.5271 & 0.0226 & $3>1$ \\
Eucalanus bungii AM & 2.3491 & 4.2658 & 2.0625 & 0.2708 & \\
Calanus marshallae III & 0.0000 & 1.1482 & 1.0138 & 0.0737 & \\
Calanus marshallae IV & 1.0471 & 1.4207 & 1.0114 & 0.0320 & $1=2=3$ \\
Calanus marshallae V & 1.0148 & 1.1988 & 1.0003 & 0.0242 & $3<1$ and 2 \\
Metridia pacifica IV & 1.3603 & 1.2162 & 0.0000 & 0.1085 & \\
Metridia pacifica V & 3.6081 & 2.5927 & 1.0035 & 0.0100 & $1>3$ \\
Metridia pacifica AF & 1.0341 & 1.6312 & 0.0000 & 0.0079 & $3<1$ and 2 \\
Scolecithricella minor V & 1.0805 & 1.6740 & 0.0000 & 0.3794 & \\
Pseudocalanus AF & 1.3518 & 1.2374 & 1.0037 & 0.4023 & \\
Euphausiid eggs & 1.1150 & 1.5399 & 1.6124 & 0.1403 & \\
Euphausid furcilia & 4.8978 & 4.9403 & 2.6923 & 0.1104 & \\
Parathemisto pacifica & 4.3469 & 3.4178 & 2.5750 & 0.1562 & \\
Sagitta elegans & 4.1167 & 2.9090 & 1.4797 & 0.0004 & $3<1$ and 2 \\
Eukhronia hamata & 1.2124 & 1.6501 & 1.1999 & 0.3750 & \\
Limacina helicina & 2.7485 & 2.1441 & 2.8542 & 0.4240 & $1>2$ \\
Clione limacina & 2.2062 & 1.4371 & 1.7251 & 0.0195 & $1>1$ \\
Aglantha digitale & 1.1602 & 1.5444 & 1.9533 & 0.0312 & $3>1$ \\
& & & & & \\
\hline
\end{tabular}

Aleutian Islands. Water south of the Aleutians therefore originates in the Pacific hundreds of kilometers to the east of the study site. Thus, local Bering Sea hydrographic and climatic conditions may have influenced the species composition, abundance, timing and duration of successional events in the zooplankton north of the Bering Sea front, whereas hydrographic and climatic conditions along the central and eastern Gulf of Alaska shelf break influenced zooplankton in Alaska Stream water.

The lower temperatures in the Bering Sea relative to the Pacific probably retard the timing of successional events in the plankton community in the Bering relative to Alaska Stream water. The population modes of the copepodid stages of Neocalanus flemingeri are ahead of those of $N$. plumchrus by about 1 mo (Miller \& Clemons 1988, Mackas et al. 1993). While N. flemin- geri was dominant relative to $N$. plumchrus north of the Aleutians, south of the Aleutians N. flemingeri had apparently completed its foraging and descended out of the upper mixed layer prior to our sampling season. This is consistent with the observation that $N$. flemingeri copepodid stage $\mathrm{V}$ were more abundant than $N$. plumchrus $V$ below $100 \mathrm{~m}$ depth in Pacific water.

Eucalanus bungii copepodid stages III and IV occur in the upper water column, predominantly below the thermocline, from May through July in the north Pacific gyre (Miller et al. 1984). The E. bungii copepodid stages we observed in Alaska Stream water are therefore consistent with the Pacific observations. E. bungii consist primarily of nauplii and copepodid stages I and II in the Kamchatka Basin (Fig. 13) in June (Kolosova et al. 1987, Kulikov 1990), stages II and III dominate north of Attu Island in the western Aleutians (Kulikov 1990) and the earlier copepodids apparently reach stages III and IV in the Bering Sea by fall (Geynrikh 1990). The above observations suggest a delayed successional pattern for early copepodid stages of $E$. bungii as well as Neocalanus spp. in Bering Sea water relative to the Alaska Stream.

Although the relative abundance of copepodid stages of Neocalanus plumchrus, $N$. flemingeri and Eucalanus bungii were consistent for Bering Sea and Pacific water in both 1992 and 1995, high abundance of $N$. cristatus was characteristic of Bering Sea water in 1992 only. Since $N$. cristatus was the major sound-scattering organism (Coyle in press) and dominated the zooplankton biomass north of the Aleutians in June 1992, its absence substantially lowered the $\mathrm{ADB}$ in Bering Sea water in 1995. The high densities of $N$. cristatus in 1992 may have been due to an unusual flow regime resulting in different source populations for zooplankton in the upper water column north of Kiska and Buldir Islands in June. The degree of influence of Alaska Stream water north of Kiska and Buldir Islands depends on flow into the Bering Sea. Multiannual geostrophic data (Arsenev 1967, Reed et al. 1993), heat balance computations (Batilin 1964, Vasyukova 1964; see Pavlov \& Pavlov 1996), drifters (Stabeno \& Reed 1994) and model simulations (Overland et al. 1994) all indicate that a substantial amount of Alaska Stream water nor- 


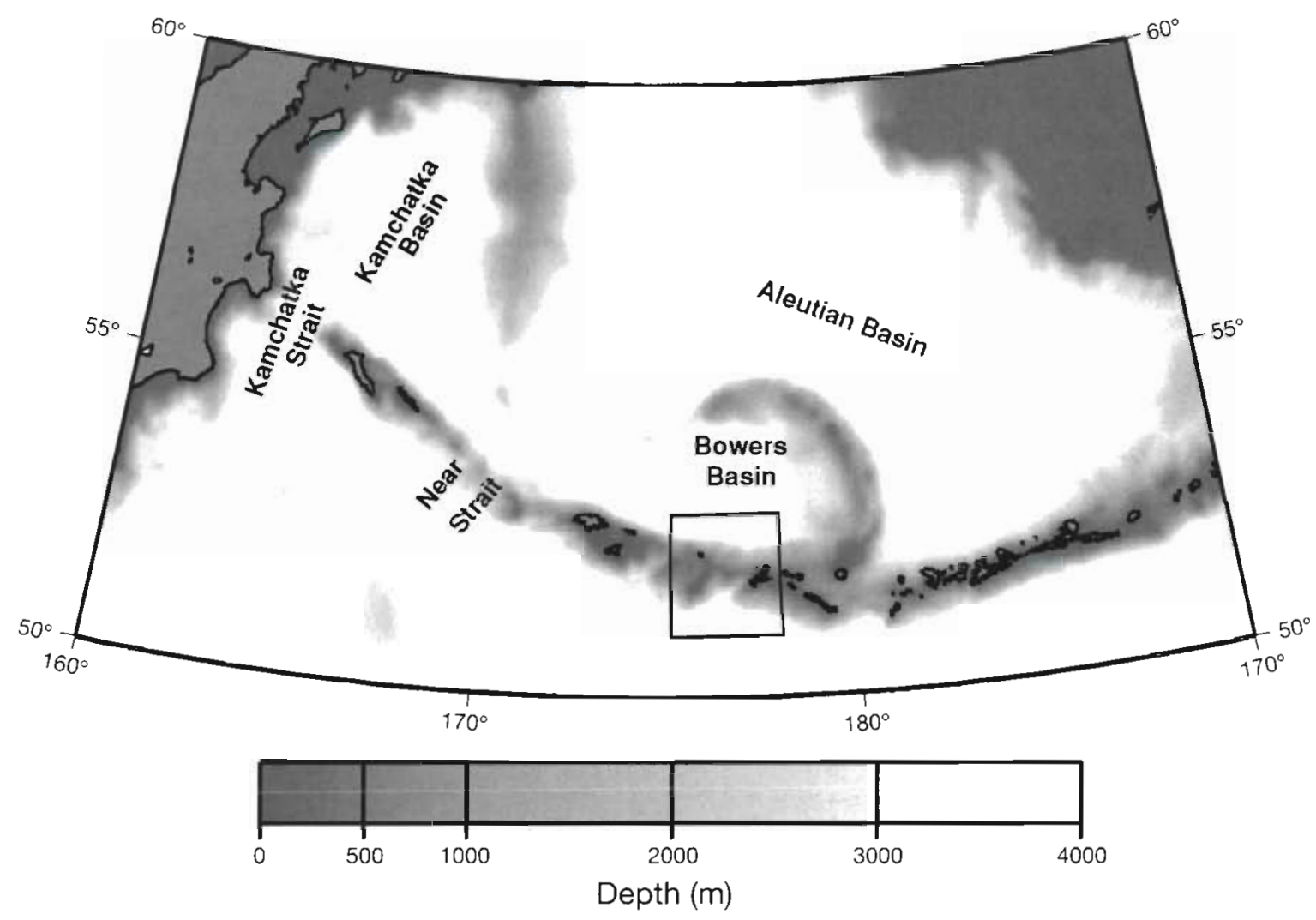

Fig. 13. Aleutian archipelago and the major bathymetric and geographic features in the southwestern Bering Sea. Boxed inclosure denotes study area

mally flows northward through Near Strait (Fig. 13) into the Bering Sea. A portion of the northward flow turns eastward and can form an eddy in Bowers Basin north of Kiska Island (Stabeno \& Reed 1994).

Occasionally, flow of Alaska Stream water through Near Strait can be suspended (Stabeno \& Reed 1992, Reed \& Stabeno 1993). Under such conditions, at least some of the source water in the eddy north of Kiska is from the Kamchatka Basin, as indicated by drifters (Stabeno \& Reed 1992). Therefore, under conditions of suspended flow of Alaska Stream water through Near Strait, a greater portion of the local zooplankton population may originate in the Kamchatka Basin, whereas under conditions of elevated flow through the pass, more of the local zooplankton population will have originated in the Pacific.

Long-term plankton surveys in the upper $80 \mathrm{~m}$ of the Bering Sea indicate elevated zooplankton biomass in the Kamchatka Basin (Motoda \& Minoda 1974). Neocalanus cristatus commonly dominates in the upper $100 \mathrm{~m}$ of the Kamchatka Basin and often occurs at densities of up to 3000 ind. $\mathrm{m}^{-2}$ and biomass of $110 \mathrm{~g} \mathrm{~m}^{-2}$ (Lubny-Gertsyk 1961). Dense concentrations of $N$. cristatus have been reported in surface waters of the Oyashio Current in the northwestern Pacific (Tsuda et al. 1993, Tsuda 1995). The Oyashio is a cold current flowing southward out of the Bering Sea through Kamchatka Strait. Thus, the elevated zooplankton biomass in the Kamchatka Basin may be in part due to high densities of $N$. cristatus.

Flow of Alaska Stream water through Near Strait was suspended in 1991 and drift drogues showed flow from the Kamchatka Basin eastward to Kiska Island (Stabeno \& Reed 1992). Flow through Near Strait was reestablished by fall of 1992 (Reed \& Stabeno 1993). Thus, our sampling period in June 1992 occurred during or shortly after the period of reduced flow through Near Pass. Zooplankton advected from the Kamchatka Basin into the eddy in Bowers Basin in 1991 may have been the source of the elevated densities of $\mathrm{NeO}$ calanus cristatus observed in Bering Sea water during June 1992.

Model simulations using wind data from 1985 to 1992 indicate that transport through Aleutian Island passes may be influenced by long-term variations in wind stress curl over the Pacific (Overland et al. 1994). In addition, instabilities producing large-scale eddies in the Alaska Stream near the central Aleutian Islands can also influence circulation through the passes and in the southern Aleutian basin (Okkonen 1996). Sus- 
pension of flow through the passes causes lower surface water temperatures, higher surface salinities, deeper winter convective mixing and lower temperatures in the intermediate layer on the Bering Sea side of the Aleutians (Stabeno \& Reed 1992). The lower temperatures probably retard successional stages in the plankton community in resident Bering Sea water relative to those in Alaska Stream water.

In conclusion, the differences in the relative abundances of Neocalanus plumchrus and $N$. flemingeri. and the developmental stages of Eucalanus bungii north and south of the Aleutian Islands, are consistent with the retarding affect that the cold Bering Sea Intermediate water would have on the developmental rates of zooplankton in the Bering Sea relative to the Pacific. The elevated biomass in the Bering Sea relative to the Pacific is at least partially due to periodic episodes of elevated densities of $N$. cristatus north of the Aleutians. Interannual differences in $N$. cristatus densities may be related to differences in the flow regimes carrying zooplankton source populations into Bowers Basin from either the Pacific or the Kamchatka Basin. The above data clearly demonstrate the value of acoustic remote sensing for documenting associations of zooplankton biomass with water masses, frontal systems and pycnoclines.

Acknowledgements. We thank the captain and crew of the RV 'Alpha Helix' for their enthusiastic cooperation with our research efforts during the cruise. The graduate students and technicians of G.L.H. assisted during field collections. Shelton Gay aided in collection of the physical data. Technical assistance with the MOCNESS and acoustics was provided by Michelle Miller, Steve Hartz and Mark Valarino. Technical assistance in processing zooplankton samples was provided by Elizabeth Stockmar. Software for spatial statistics was written by John Kern, West Inc., Cheyene, Wyoming, USA. We thank all of the above for their participation in this research effort. The research project was funded by National Science Foundation, Office of Polar Programs, grants DPP912283 and DPP-9321636.

\section{LITERATURE CITED}

Arsenev VS (1967) Currents and water masses in the Bering Sea. Nauka Press, Moscow (English translation by S. Pearson, 1968, US Dept Commerce, National Marine Fisheries Service, Seattle)

Batilin AM (1964) Water exchange between the Bering Sea and Pacific Ocean. Tr Vses Nauchno-Issled Inst Morsk Rybn Khoz Okeanogr 49:7-16 (English translation, 1968. In: Soviet fisheries investigations in the northeastern Pacific, Part 2:1-12. US National Technical Information Service, TT 67-51024)

Brodsky KA (1957) The copepod fauna (Calanoida) and zoogeographic zonation in the North Pacific and adjacent waters. Izd Akad Nauk SSSR, Leningrad

Coyle KO (in press) Acoustic assessment of Neocalanus scattering layers near the western Aleutian Islands. J Plankton Res
Coyle KO, Chavtur VG, Pinchuk AI (1996) Zooplankton of the Bering Sea. In: Mathisen OA, Coyle KO (eds) Ecology of the Bering Sea: a review of the Russian literature. Alaska Sea Grant College Program Rep No. 96-01, University of Alaska, Fairbanks, p 97-133

Geynrikh AK (1990) Abundance of the major oceanic copepod species in the Bering Sea. Biol Morya 2:14-18

Isaaks EH, Srivastava RM (1989) An introduction to applied geostatistics. Oxford University Press, New York

Kolosova EG, Kulikov AS, Kosobokova KN (1987) Studies of zooplankton in the Bering Sea. 5.1 Mesozooplankton of the Bering Sea. In: Izraelya Yu A, Tsyban' AV (eds) Comprehensive analysis of Bering Sea ecosystems. Gidrometeoizdat, Leningrad, p 141-174

Kulikov AS (1990) Mesoplankton. In: Izraelya Yu A. Tsyban AV (eds) Research on Bering Sea ecosystems. Gidrometeoizdat, Leningrad, p 122-141

Lubny-Gertsyk EA (1961) The distribution of the major zooplankton species in the Gulf of Kamchatka and KorfoKaraginskiy in August-September 1956, from tows taken on the R/V Akademik Shuleykin. Trud Inst Okeanol Akademiya Nauk SSSR 51:112-115

Mackas DL, Sefton H, Miller CB, Raich A (1993) Vertical habitat partitioning by large calanoid copepods in the oceanic subarctic Pacific during spring. Prog Oceanogr 32:259-294

Miller CB, Clemons MJ (1988) Revised life history analysis for large grazing copepods in the subarctic Pacific Ocean. Prog Oceanogr 20:291-313

Miller CB, Frost BW, Batchelder HP, Clemons MJ, Conway RE (1984) Life histories of large, grazing copepods in a subarctic ocean gyre: Neocalanus plumchrus, Neocalanus cristatus and Eucalanus bungij in the northeast Pacific. Prog Oceanogr 13:201-243

Motoda S, Minoda T (1974) Plankton of the Bering Sea. In: Hood DW, Kelley EJ (eds) Oceanography of the Bering Sea with emphasis on renewable resources: proceedings of an international symposium, Hokkaido, Japan, 1972. Univ Alaska Inst Mar Sci Occas Publ No. 2, Fairbanks, p 207-241

Okkonen SR (1996) The influence of an Alaskan Stream eddy on flow through Amchitka Pass. J Geophys Res 101(C4): 8839-8851

Overland JE, Spillane MC, Hurlburt HE, Wallcraft AJ (1994) A numerical study of the circulation of the Bering Sea basin and exchange with the North Pacific Ocean. J Phys Oceanogr 24:736-758

Parsons TR, Maita Y, Lalli CM (1984) A manual of chemical and biological methods for seawater analysis. Pergamon Press, Oxford

Pavlov VK, Pavlov PV (1996) Oceanographic description of the Bering Sea. In: Mathesin OA, Coyle KO (eds) Ecology of the Bering Sea: a review of the Russian literature. Alaska Sea Grant College Program Rep No. 96-01, University of Alaska, Fairbanks, p 1-95

Reed RK (1984) Flow of the Alaska Stream and its variations Deep Sea Res 31(4):369-389

Reed RK, Khen GV, Stabeno PJ, Verkhunov AV (1993) Water properties and flow over the deep Bering Sea basin in summer 1991 Deep Sea Res 40(11/12):2325-2334

Reed RK, Stabeno PJ (1993) The recent return of the Alaskan Stream to Near Strait. J Mar Res 51:515-527

Stabeno PJ, Reed RK (1992) A major circulation anomaly in the western Bering Sea. Geophys Res Lett 19(16): $1671-1674$

Stabeno PJ, Reed RK (1994) Circulation in the Bering Sea basin observed by satellite-tracked drifters: 1986-1993. J Phys Oceanogr 24:848-854 
Tsuda AH (1995) Fractal distribution of an oceanic copepod Neocalanus cristatus in the subarctic Pacific. $J$ Oceanogr 51:261-266

Tsuda A, Sugisaki H, Ishimaru T, Saino T, Sato T (1993) White-noise-like distribution of the oceanic copepod Neocalanus cristatus in the subarctic North Pacific. Mar Ecol

Editorial responsibility: Otto Kinne (Editor), Oldendorf/Luhe, Germany
Prog Ser 97:39-46

Vasyukova NG (1964) Heat balance in the surface waters of several fisheries regions in the Bering Sea. Tr Vses Nauchno-Issled Inst Morsk Rybn Khoz Okeanogr 49:77-92 Vinogradov ME (1956) Zooplankton distribution in the western Bering Sea. Tr Vses Gidrobiol O-va 7:174-203

Submitted: May 22, 1996; Accepted: February 16, 1998

Proofs received from author(s): April 16, 1998 